\title{
防火対策の設置と信頼度が避難安全性と防火コス卜に及ぼす影響 THE EFFECT OF FIRE PREVENTION DEVICES SET OR NOT AND RELIABILITY FIREPROOF COST AND SAFETY IN EVACUATION
}

\author{
中野美奈*, 油野健 志*, 湯谷孝夫**, 室崎益輝*** \\ Mina NAKANO, Kenji ABURANO, Takao YUTANI \\ and Yoshiteru MUROSAKI
}

\begin{abstract}
Fire prevention planning is based on requirements in building regulations and laws. It's unclear how much its effective safety is. It usually doesn't consider its cost. Building regulations and laws will be rewritten on the performance in fire prevention. This paper suggests the system that evaluates life safety, and that considers the fireproof cost. This system estimates the cost with public data and estimates life safety with the comparison of smoke behavior and people's one under fire. Finally we applied this system to a model of office building and made clear effective fire prevention planning and their combination.
\end{abstract}

Keywords : life safety, fireproof cost, fire prevention device, reliability 避難安全性, 防火コス卜, 防火設備, 信頼度

\section{1.はじめに}

近年，建築物は大規模化，複合化し，それらに対応した防火対策 の充実が求められる一方でコスト低減のニーズも高く，合理的な防 火計画が必要とされている。しかし，現状では防火対策の実施が安 全性に及ぼす影響が明らかでないため，設計実務者も防火計画の安 全性に疑問を感じているわ。過制な，あるいは無駄な防火計画がなさ れている可能性もあるが，それらを明確に示寸手法が確立されてい ない。

建築基準法改正に向けて, 性能的基準にもとづく火災安全設計法 の議論が盛んである。防火計画についても, 安全性をどれだけ担保 しているかという性能を評価する手法が求められている。安全性評 価の手法が明確になれば，画一的な防火計画ではなく，建物の用途 や使われ方に合わせて同等の安全性を保ちつつ様々な防火計画を選 択できることになる。またそのうえで，費用対効果を把握すること により，効率的な防火計画の選択も可能となる。

過去には, 火災安全性評価手法の研究として, 焼損面積期待值に よる評価法や，イベントツリーによるケース生起確率と火災子測計 算による評価法 ${ }^{2}$, 防火設備の信頼性を考慮した火災シナリオに基 づいた避難安全性の評価手法3’がある。

一方，防火コストの研究として，防火対策に関わるコストの現状 を調查し，建物用途や規模（階数・面積）と防火コス卜との関係を 分析した研究4),55あるは設計者に対するアンケート調査により，防 火コストの実態や意識を調查した研究6)等があるが, 総じて防火コ
ストに関する研究は数少ない。

また，安全性と防火対策に関わるコストとの関係の研究として， 防火対策の有効度・信頼度を用いて, 維持管理の善し悪しという側 面から安全性と防火コストの関係を分析した研究7がある。この中 では，安全性を建築物の焼損面積期待值で評価しており，避難安全 性は評価の指標に入れられていない。

本研究では防火計画において，コストを考慮に大れた防火对策の 安全性評価手法を提案し,この評価手法を用いて様々な用途, 規模 の建物について合理的な防火計画が提案できるようになることを目 的とする。このなかで安全性」表す指標については，「避難安全性」 を用いた。「避難安全性」は，人命に最も影響を与えると考えられる 煙流動状況と避難行動を予測することにより求めた。その際，防火 对策がもつ信頼度を「避難安全性」に組み入れることにより，より 現実に近い評価ができるものと考える。

そこで本報では事務所ビルを例にとり，4つの防火対策(自火報, スプリンクラー, 防火戸, 排煙設備)の任意の組み合わせについて, 防火对策個々の，また組み合わせによる効果をコス卜の面から計量 的に評価しようと試みた。また，任意の組み合わせによる防火対策 の効果と防火コストについておおまかに評価手法の概念を示し，コ ストを考慮した防火計画の評価手法の提案を試みた。

\footnotetext{
$*$ 鴻池組技術研究所 研究員 -工修

** 渒池組技術研究所 主任研究員 - 工修

*** 神戸大学都市安全研究センター 教授・工博
}

Research Engineer, Research Institute of Technology, Konoike Construction, M. Eng.

Chief Research Engineer, Research Institute of Technology, Konoike Construction, M. Eng.

Prof., Research Center for Urban Safety and Security, Kobe University, Dr. Eng. 


\section{2. 研究の概要}

\section{1 研究のフロー}

研究のフローを図 1 に示す。本研究では「避難安全性」の評価方 法と「防火コスト」の求方を個々に示し, 次にそれらの方法を用 いてケーススタディを行い，防火コストと避難安全性との関係を分 析する。

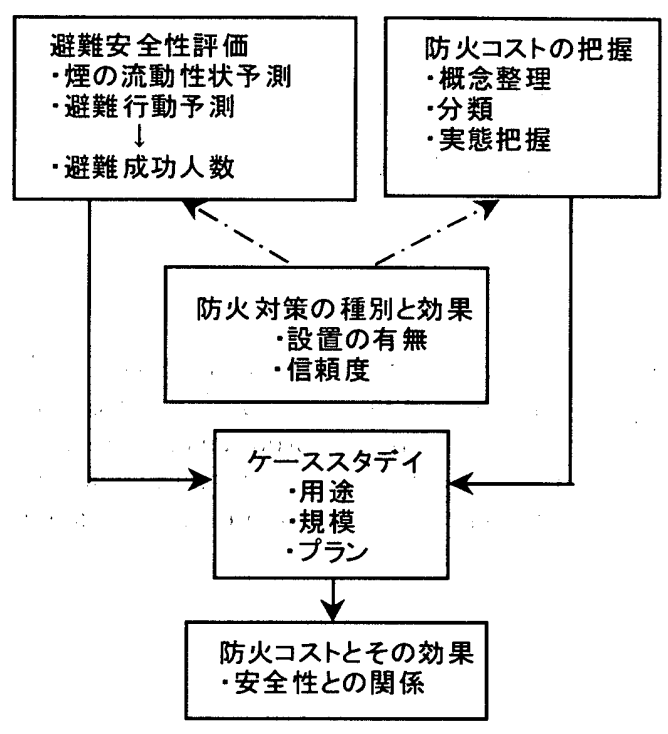

図 1 研究のフロー

\section{2 用語の定義}

ここでは避難安全に関わる用語を以下のように定義する。

(1) 避難安全性 $: \operatorname{Pr}\left(\right.$ 人/棟 $\cdot \mathrm{m}^{2} \cdot$ 年)

「防火対策の信頼度を考慮した避難成功人数」

$P r=P a \times R a / 100+P a n \times(1-R a / 100)$

$P a:$ 対策 $\mathrm{A}$ が設置されているときの避難成功期待值

$R a ：$ 対策 $\mathrm{A}$ の信頼度 $(\%)$

Pan：対策 A が設置されていないときの避難成功期待值

（2）避難成功期待值：P(人/棟・ $\mathrm{m}^{2} \cdot$ 年)

「1年間のうちある建物で火災が発生したとき, 単位床面積あたり 全館で煙にまかれることなく避難に成功する人の数」

$P=F \times E$

$F$ : 用途別 ·延床面積別推定出火率

$E:$ 避難成功人数

(3) 用途別・延床面積別推定出火率：F（回 $/ \mathrm{m}^{2} \cdot$ 年)

「 1 年間のう污対象とする用途の建物で単位床面積あたり出火す る確率」

（4）避難成功人数：E（人/回・棟）

「ある建物で出火したとき,全館で煙にまかれることなく避難に成 功する人の数」

（5）避難限界となる煙層下端高さ：S(m)

避難完了まで, 煙層高さ $S h$ について以下の条件が満足されるこ とが求められる8

$S h<1.6+0.1(H-h)$

$S h ：$ 煙層境界の火源位置からの高さ $(\mathrm{m})$

$H$ : 炏源位置からの空間天井高さ $(\mathrm{m})$ $h:$ 火源位置からの避難床高さ $(\mathrm{m})$

$h=0$ のとき, ある笁間で避難限界となる煙層下端高さ $S$ は $S=$ $1.6 \mathrm{~m}+0.1 H$ ( $H:$ 空間の天井高さ $)$ となる。

(6) 避難限界時間 $(S)$

「避難限界となる煙層下端高さ（S）になる時間」

(7) 避難完了時間 $(S)$

「最終避難者が第 2 次安全区画である階段附室または階段室に入 ク込んだ時間」

\section{3．避難安全性の評価手法}

3.1 シナリオ

本研究における防火对策の位置づけを含めた安全性評価手法の概 念図を図 2 に示す。避難安全性を評価するために，火災のシナリオ と避難のシナリオを独立して設定し，時間軸で比較している。

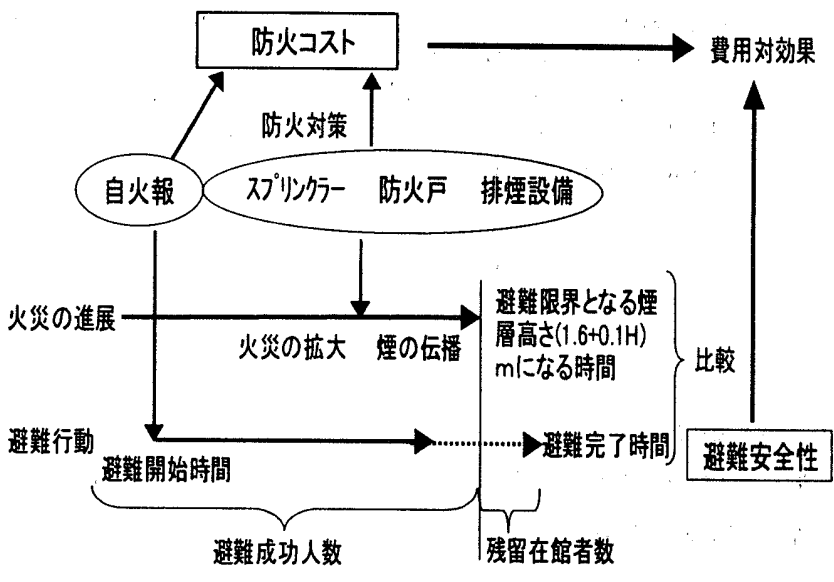

図 2 避難安全性評価の概念困

火災のシナリオで煙の流動状況を把握し，避難限界となる煙層下 端高さになる時間に, 避難を完了している避難成功人数によっで建 物全体の「避難安全性：Pr」を評価する。これはある建物について 1 年間に火災が発生した際, 避難に成功した人数で評価するので, 単位は（人/棟・ $\mathrm{m}^{2} \cdot$ 年）とする。

1.) 火災のシナリオ

火災の進展に伴う煙の流動状況は,「2 層ゾーン煙流動性状予測プ

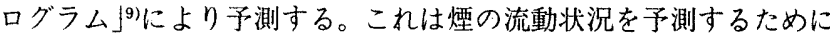
一般に使われている，多数階多数室を対象とする非定常煙流動予測 モデルである。空間の形状, 開口部の大きさ, 開閉状況, 火源の拡 大状況等の条件を与之ると, 出火後の任意の時刻における各空間内 の温度，煙層高さ，圧力などを予測する。

本研究では火災室, 非火災室ともに, 避難限界となる煙層下端高 巳 $1.6+0.1 H(\mathrm{~m})$ になる時間を求める。

2) 避難のシナリオ

避難行動を予測するために「避難性状予測プログラム」99を使用す る。これは「避難者は設計者が避難路として計画した通路を整然と 混乱なく避難する」ことを前提に，在館者が避難以前にいた場所か ら最終避難場所に到達するまでの一連の行動の流れを追うことがで きる。避難行動を大きく決定づける要因として, 避難開始時間の設 定があるが，これは火災室と非火災室とで異なる。詳細は3.2 1) 
(1)で述べる。

\section{2 防火対策}

1）防火対策項目

防火対策とは火災の進展を抑制する対策（消火設備，防火区画）, 煙の伝播を抑制する対策(排煙設備, 防煙区画), 避難行動を円滑に する対策 (自動火災報知設備, 避難器具) 等がある。この中から火 災の進展状況に応じて操作や作動が必要な対策を対象とし, 防火対 策上最も有効と考之られる, 自動火災報知設備 (以下, 自火報), 又 プリンクラー, 防火戸, 排煙設備（機械排煙）の 4 つの防火対策を シナリオのパラメーターとして用いる。防火対策の選定や設置につ いては, 建築基準法の性能規定化をふまえ, 本報では現行の法令に とらわれず設定している。

火災の拡大や避難行動のなかで，それぞれの対策が影響を及ぼす 項目とそれぞれの設定值を以下に述べる。

\section{(1) 自火報の前提条件}

自火報が設置されている場合, 火災室の在館者は自火報の作動と 同時に避難を開始し，非火災室では出火室の 2 倍の時間がかかるも のとする ${ }^{10)}$ 。自火報の作動時間は一般に作動に必要とされる時間と して60秒と仮定すると, 火災室では出火後60秒, 非火災室では出火 後120秒で避難を開始すると仮定する。

自火報が設置されていない場合, 煙の認知により避難が開始され るとし, 認知可能な煙層厚さ（天井高さの 1 割）になった時間を避 難開始時間とする。火災室, 非火災室ともに, 空間の煙層下端高さ が(4)の式を満たしたときに避難を開始するものとする ${ }^{11)}$ 。

$H s=0.9 H C$ $\cdot(4)$

$H c:$ 空間の天井高 $(\mathrm{m})$

$H s:$ 空間の煙層下端高さ $(\mathrm{m})$

(2) スプリンクラーの前提条件

初期火災の想定火源として文献8にある標準火源を用途に応じて 用いる (表 1 )。

表 1 想定火源の発熱速度8)

\begin{tabular}{|c|c|c|c|c|c|}
\hline \multirow{3}{*}{ 火源NO. } & \multicolumn{4}{|c|}{ 設定値 } & \multirow{3}{*}{ 用途 } \\
\hline & \multicolumn{2}{|c|}{ 時間(S) } & \multicolumn{2}{|c|}{ 発熱速度 $(\mathrm{kW})$} & \\
\hline & $t 1$ & $t 2$ & Q1 & Q2 & \\
\hline 火源NO. 1 & 120 & 240 & 300 & 3,000 & 事務室等 \\
\hline 火源NO. 2 & 120 & 320 & 750 & 25,000 & 物販店舗等 \\
\hline 火源NO. 3 & 480 & 720 & 200 & 1,000 & 宿泊室、病室等 \\
\hline
\end{tabular}

スプリンクラーの作動開始時間は発熱速度 $Q$ が, 以下の式を満た した時間とする ${ }^{8)}$ 。

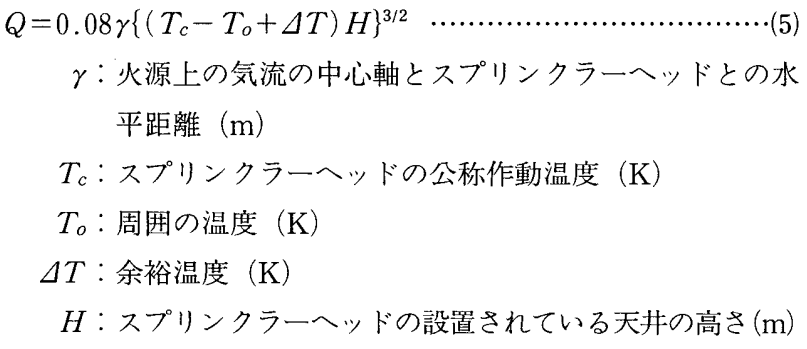

$\gamma$ : 火源上の気流の中心軸とスプリンクラーヘッドとの水 平距離 $(\mathrm{m})$

$T_{c}$ : スプリンクラーヘッドの公称作動温度 $(\mathrm{K})$

$T_{o}$ : 周囲の温度 $(\mathrm{K})$

$\Delta T:$ 余裕温度 $(\mathrm{K})$

$H$ : スプリンクラーヘッドの設置されている天井の高さ $(\mathrm{m})$ スプリンクラーが設置されていない場合は, 想定した火源のとお クに発熱速度が增大するものとする。

(3) 防火戸の前提条件
防火戸は種類により出火から閉鎖までの時間を設定する。防火户 が設置されていない埸合，開口部は常に全開とする。

(4) 排煙設備の前提条件

排煙設備も種類により出火から開放（起動）までの時間を設定す る。

2) 防火対策の信頼度

防火対策は設置すれば効果があるというものではなく，防火設備 自体の機械の故障など現状では有効に作動しない場合も多い。本研 究では防火対策が作動する確率を「防火对策の信頼度」と定義する。 また作動し，かつ，その機能を果たすことの指標として「奏功率」 があるが，今回はパラメーターには含めない。不奏功の例としては， 防火シャッターや防火扉の部分に荷物などが置いてあり閉鎖障害と なって機能しないという, 維持管理に問題のある場合などがあげら れる。

それぞれの防火対策の信頼度は, 過去の統計デー夕3)を用いて, 表 2のように設定する。

表 2 防火対策の信頼度 ${ }^{3 \prime}$

\begin{tabular}{|l|r|}
\hline & 信頼度 \\
\hline 自火報 & 0.93 \\
\hline スプリンクラー & 0.98 \\
\hline 防火戸(堅穴区画) & 0.9 \\
\hline 排煙設備 & 0.95 \\
\hline
\end{tabular}

\section{4. 防火コストの算定方法}

本研究では防火コストとは,「各種の防火対策に関わるイニシャル コスト，ランニングコスト（建物の火災保険料を含む）」をいう。

\section{1 イニシャルコスト}

防火対策のイニシャルコストは市販の見積資料 ${ }^{22} に よ り$ 表 3 のよ うに設定されている。

自火報, スプリンクラー, 排煙設備は延べ面積あたりの単価が, 延べ面積 $30,000 \mathrm{~m}^{2}, 15,000 \mathrm{~m}^{2}, 6,000 \mathrm{~m}^{2}, 3,000 \mathrm{~m}^{2}$ ごとに示されてい る。防火戸については既往の研究〕を参照した。

表 3 防火対策の単(価(12)

\begin{tabular}{|c|c|c|c|c|c|}
\hline 防火対策 & $30000 \mathrm{~m}^{2}$ & $15000 \mathrm{~m}^{2}$ & $6000 \mathrm{~m}^{2}$ & $3000 \mathrm{~m}^{2}$ & 単位 \\
\hline 自火報 & 6,260 & 5,680 & 2,910 & 2,910 & $\left(\right.$ 円/延 $\left.\mathrm{m}^{2}\right)$ \\
\hline スプリタラー- & 4,700 & - & - & - & $\left(\boldsymbol{P} / \mathbf{3} \leq \mathrm{m}^{2}\right)$ \\
\hline 防火戸 & 300,000 & 300.000 & 300,000 & 300,000 & (円/枚) \\
\hline 排煙設備 & 2,270 & 690 & 310 & & $\left(\right.$ 円 / 延 $\left.\mathrm{m}^{2}\right)$ \\
\hline
\end{tabular}

\section{2 ランニングコスト}

本研究では, ランニングコストには, 保全業務費, 人件費, 火災 保険料が含まれる。

1）保全業務費

保全業務費は, 直接人件費, 直接物品費, 業務管理費, 一般管理 費からなる。

直接人件費 $=$ 工数 $\times$ 基礎単価

直接物品費 $=$ 直接人件費 $\times$ 直接物品費率

業務管理費 $=$ 直接業務費 $*$ 業務管理費率 
一般管理費 $=$ 業務原価**×般管理費等率

$*$ 直接業務費 $=$ 直接人件費 + 直接物品費

$* *$ 業務原価 $=$ 直接業務費十業務管理費

基礎単価は, 技術者区分により異なるが，ここではすべて技術員 が保全業務を行うものとする。技術員の基礎単価は $1,370 \sim 1,530$ (円/時間)である13)。また，それぞれの防火対策の保全業務に関わる 工数は文献 ${ }^{14}$ により求める。

\section{2）火災保険料}

火災保険料とは，保険金額（保険をつける建物，または動産の金 額）に保険料率（保険金額1,000円に対する 1 年分の掛け金）を乗じ たものである。火災保険料は工事原価のうち，基礎や外構にかかる 費用を除いた金額に掛ける場合が多い。ここでは軀体工事，仕上げ 工事，設備工事を合わせた工事原価に保険を掛けるものとする。

火災保険料 $=($ 保険を掛ける $)$ 工事原価 $\times$ 保険料率

保険料率は, 建物の構造, 職業 (用途), 階数, 設置されている消 火設備により増減がある。

\section{5.ケーススタディ}

以上の評価方法に基づいて，ある建 築物を想定し，設置する防火対策の組 み合わせを変えた CASE 1 〜 CASE16（表 4）についてケースス夕 ディを行う。

\section{1 モデル建築物の概要}

モデル建築物の概要を図 3 に示す。

$\begin{array}{ll}\text { 所在地 } & : \text { 東京都2等地 } \\ \text { 構造 } & : \text { SRC造 } \\ \text { 用途 } & : \text { 事務所ビル } \\ \text { 階数 } & : 5 \text { 階建て } \\ \text { 基準階面積 } & : 2,000\left(\mathrm{~m}^{2}\right) \\ \text { 延床面積 } & : 10,000\left(\mathrm{~m}^{2}\right) \\ \text { 天井高 }(\mathrm{H}) & : 2.7(\mathrm{~m}) \\ \text { 在館者密度 } & : 0.2\left(人 / \mathrm{m}^{2}\right) \\ \text { その他 } & : 1 \mathrm{Fl} \text { 防災センター }\end{array}$

表 4 防火対策設定例

\begin{tabular}{|c|c|c|c|c|}
\hline & $\begin{array}{l}\text { 自 } \\
\text { 火報 }\end{array}$ & \begin{tabular}{|l|}
$R 7^{\circ} \|$ \\
ンクラ-
\end{tabular} & $\begin{array}{l}\text { 防 } \\
\text { 火 } \\
\text { 户 }\end{array}$ & $\begin{array}{l}\text { 排 } \\
\text { 煙 } \\
\text { 設 } \\
\text { 備 }\end{array}$ \\
\hline CASE 1 & $x$ & $x$ & $x$ & $x$ \\
\hline CASE 2 & 0 & $x$ & $x$ & $x$ \\
\hline CASE 3 & $x$ & 0 & $x$ & $x$ \\
\hline CASE 4 & $x$ & $x$ & 0 & $x$ \\
\hline CASE 5 & $x$ & $x$ & $x$ & 0 \\
\hline CASE 6 & 0 & 0 & $x$ & $x$ \\
\hline CASE 7 & 0 & $x$ & 0 & $x$ \\
\hline CASE 8 & 0 & $x$ & $x$ & 0 \\
\hline CASE 9 & $x$ & 0 & 0 & $x$ \\
\hline CASE10 & $x$ & 0 & $x$ & 0 \\
\hline CASE11 & $x$ & $x$ & 0 & 0 \\
\hline CASE12 & 우 & 0 & 인 & $x$ \\
\hline CASE13 & $x$ & 0 & 0 & 운 \\
\hline CASE14 & 0 & $x$ & 0 & 0 \\
\hline CASE15 & 운 & 0 & $x$ & 0 \\
\hline CASE16 & 0 & 0 & 0 & 0 \\
\hline
\end{tabular}

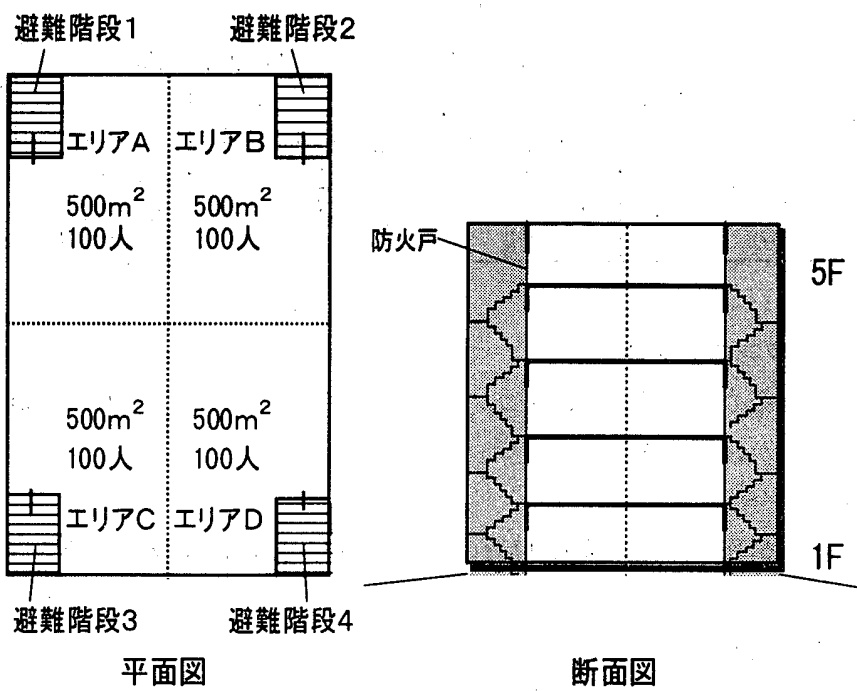

図 3.モデル建築物の概要

\section{2 避難安全性の算出 \\ 1 ）防火対策前提条件 \\ (1) 自火報}

自火報が設置されている場合，火災室の避難開始時間は60秒，非 火災室の避難開始時間は 120 秒とする。自火報がない場合は煙層下端 高さが式(4)を満たした時間を避難開始時間とする。

(2) スプリンクラー

スプリンクラーが設置されている場合, $\gamma=3 \mathrm{~m}, T_{c}=346 \mathrm{~K}, T_{o}=$ $293 \mathrm{~K}, \Delta T=20 \mathrm{~K}$ と設定すると，Q=664.1kWになったときスプリ ンクラーが作動を開始すると仮定される。モデル建築物の用途は事 務所なので標準火源 N0.1の時間と発熱速度との関係を用いて火源 の成長を予測する ${ }^{8)}$ と， $Q=664.1 \mathrm{~kW}$ となる時間は，出火後136秒で ある。作動開始後約60秒で鎮火するものとし, 出火後200秒で発熱速 度が $0 \mathrm{~kW}$ になると設定する(図 4 )。

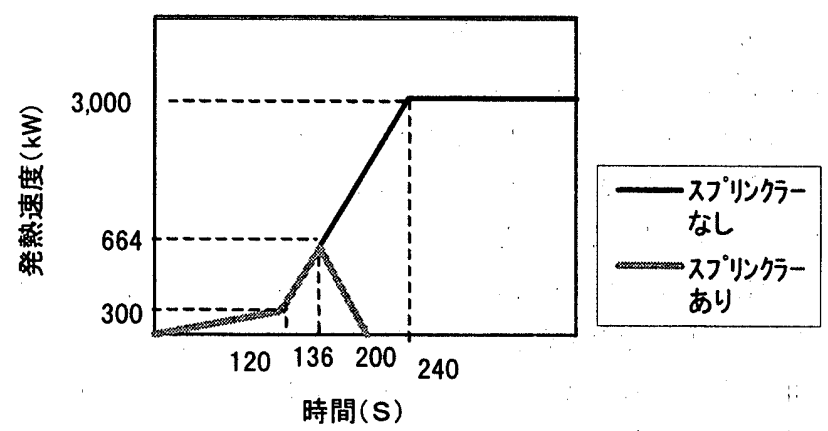

図4 標準火源 $\mathrm{N} 0: 1$ の発熱速度 ${ }^{8)}$ と設定值

(3) 防火户

防火戸は煙感知器連動とし, 防火戸が設置されている場合, 出火 後120秒で全防火戸が閉鎖すると設定する。

(4) 排煙設備

排煙設備は機械排煙で, $1 \mathrm{~F}$ の防災センタ一の管理者が現場で火災 を確認後，手動で操作するものとする。排煙設備が設置されている 場合, 出火から始動のボタンを押すまでと, ボタンを押してから排 煙機が作動するまでの時間遅れを見込んで出火後180秒で作動を完 了すると設定する。以上の結果を表 5 に整理する。

表 5. 防火对策と設定值

\begin{tabular}{|c|c|c|c|c|}
\hline & 影響する項目 & \multicolumn{2}{|l|}{ 対策あり } & 対策なし \\
\hline \multirow[t]{2}{*}{ 自火報 } & \multirow[t]{2}{*}{ 避難開始時間 } & 火災室 & 出火後 60 秒 & 煙の降下時間(数式4参照) \\
\hline & & 非火災室 & 出火後120秒 & 煙の降下時間(数式4参照) \\
\hline スプリタラー & 火源の発熱速度 & $\begin{array}{l}\text { 出火後 } 136 \\
\text { 出火後200 }\end{array}$ & $\begin{array}{l}\text { 少 } 6664.1 \mathrm{~kW} . \\
\text { 小 } 0 \mathrm{~kW}\end{array}$ & $\begin{array}{l}\text { 出火後1 20秒て300kW } \\
\text { 出火後240秒て3,000kW }\end{array}$ \\
\hline 防火戸 & 喓の伝播 & 出火後 120 & 多で閉鎖 & 常に全開 \\
\hline 排煙設㣁 & 煙の云播 & 出火後 180 & 岁で全開 & 常に閉鎖 \\
\hline
\end{tabular}

2 ) 煙流動予測結果

1 階から 5 階のそれぞれの階で出火した場合を想定し, 避難限界 となる煙層高さになる時間を各階について予測し，避難限界時間に おける全館の避難成功人数 $(E)$ を求める。その值に, 用途別·延休 面積別推定出火率 $(F)$ を乗じて, 避難成功期待值 $(P)$ を算出する。 
事務所における延床面積別推定出火率 $\left(10^{-7} \cdot\right.$ 回 $/ \mathrm{m}^{2}$ ・年 $)$ を表 6 に示す ${ }^{15)}$

\section{3 ）避難行動予測結果}

避難開始時間は，5.2 1) (1)により求める。

このモデルプランでは, エリア A にいる人は避難階段 1 に, エリ ア B にいる人は避難階段 2 に, エリア C にいる人は避難階段 3 に, エリアDにいる人は避難階段 4 に逃げ込むと仮定し, 避難動線の交 錯はないものとする。

例として CASE1の煙流動予測結果と避難成功期待值予測結果を

表 6 事務所における延床面積別推定出火率15)

\begin{tabular}{|l|l|l|l|l|l|l|r|}
\hline 規模 $\left(\mathrm{m}^{2}\right)$ & $\sim 1,000$ & $\begin{array}{l}1,001 \sim \\
3,000\end{array}$ & $\begin{array}{l}3,001 \sim \\
6,000\end{array}$ & $\begin{array}{l}6,001 \sim \\
10,000\end{array}$ & $\begin{array}{l}10,001 \sim \\
15,000\end{array}$ & $\begin{array}{l}15,001 \sim \\
20,000\end{array}$ & $20,001 \sim$ \\
\hline 事務所 $\left(\cdot 10^{-7} \cdot\right.$ & & & & & & & \\
回 $/ \mathrm{m}^{2}$.年) & - & 7.32 & 4.26 & 2.24 & 1.42 & 1.12 & 1.15 \\
\hline
\end{tabular}

表 7 避難成功期待値計算結果

\begin{tabular}{|l|r|}
\hline & $\begin{array}{l}\text { 避難成功期待値: } \\
\mathrm{P}\left(10^{-3} \cdot \text { 人 } / \text { 棟・ }\right. \\
\left.\mathrm{m}^{2} \cdot \text { 年 }\right)\end{array}$ \\
\hline CASE1 & 1.317 \\
\hline CASE2 & 1.694 \\
\hline CASE3 & 1.480 \\
\hline CASE4 & 1.538 \\
\hline CASE5 & 1.367 \\
\hline CASE6 & 1.757 \\
\hline CASE7 & 1.942 \\
\hline CASE8 & 1.769 \\
\hline CASE9 & 1.721 \\
\hline CASE10 & 1.521 \\
\hline CASE11 & 1.630 \\
\hline CASE12 & 1.898 \\
\hline CASE13 & 1.842 \\
\hline CASE14 & 1.944 \\
\hline CASE15 & 1.917 \\
\hline CASE16 & 2.017 \\
\hline
\end{tabular}

図 5 に示す。階段室の最上部に煙が滞留するまでに，最上階以外の 非火災階の階段室は污染されているが，まだ避難可能と設定し，階 段室の最上部で煙が「避難限界となる煙層高さ」まで降下した時間 に，一斉に非火災階全階が避難限界時間に達すると設定する。

非火災室の避難限界時間は, 階段室の最上部において煙が「避難 限界となる煙層高さ」にまで降下した時間とする。

以上の結果により CASE1 CASE16までの避難成功期待值：P は表 7 のおりである。

4) 避難安全性: $\mathrm{Pr}$

図 5 から求めた避難成功期待值：P 各防火対策の信頼度をも とに避難安全性：Pr を求める。

例としてCASE16について Prの求め方を表 8 に示す。

表 8 避難安全性の計算例（CASE16）

\begin{tabular}{|c|c|c|c|c|c|c|c|c|c|c|}
\hline & \multirow{2}{*}{\multicolumn{2}{|c|}{ 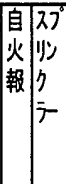 }} & \multirow{2}{*}{ 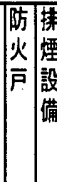 } & \multicolumn{4}{|c|}{ 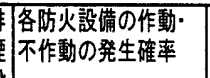 } & \multirow[t]{2}{*}{ 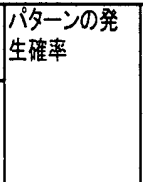 } & \multirow{2}{*}{ 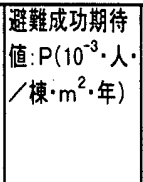 } & \multirow{2}{*}{$\begin{array}{l}\text { 避難安全性: } \mathrm{Pr} \\
\left(10^{-3} \cdot \text { 人 } / \text { 棟· }\right. \\
\mathrm{m}^{2} \cdot \text { 年) }\end{array}$} \\
\hline & & & & 自火 & 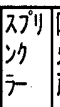 & & 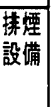 & & & \\
\hline CASE16 & 0 & 0 & 00 & - & - & - & - & 1.00 & - & 1.985363499 \\
\hline パy-ン1 & $x$ & $x$ & $\begin{array}{ll}x & x \\
\end{array}$ & 0.07 & 0.02 & 0.1 & 0.05 & 0.000007 & 1.371712 & 0.0000096 \\
\hline$\Lambda^{2} y-y^{-12}$ & 勾 & $x$ & \begin{tabular}{l|l}
$x$ & $x$ \\
\end{tabular} & 0.93 & 0.02 & 0.1 & 0.05 & 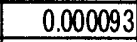 & & 1576 \\
\hline$\Lambda s 8-\div 3$ & $x$ & it & \begin{tabular}{|l|l}
$x$ & $x$ \\
\end{tabular} & 0.07 & 0.98 & 0.1 & 0.05 & & 1.480192 & 5077 \\
\hline 作 & $x$ & $x$ & $\sqrt{x}$ & 0.07 & 0.02 & 0.9 & 0.05 & 00006 & 1.538 & 0.0000969 \\
\hline 動 & $x$ & $\bar{x}$ & $x$ & 0.07 & 0.02 & 0.1 & 0.95 & 0.000133 & 1.367296 & 1819 \\
\hline$\therefore 48->6$ & t) & 4 & \begin{tabular}{l|l}
$x$ & $x$ \\
\end{tabular} & 0.93 & 0.98 & 0.1 & 0.05 & 0.004557 & 1.757056 & 0.0080069 \\
\hline 作 & से & $\bar{x}$ & $4 x$ & 0.93 & 0.02 & 0.9 & 0.05 & 0.000837 & 1.941632 & 0.0016251 \\
\hline 動 & 田 & $x$ & $x$ 直 & 0.93 & 0.02 & 0.1 & 0.95 & 0.001767 & 1.768704 & 0.0031253 \\
\hline $9 \sqrt{10} y-\dot{9}$ & $x$ & 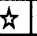 & $x$ & 0.07 & 0.98 & 0.9 & 0.05 & 0.003087 & 1.721216 & 0.0053134 \\
\hline $1 \%-j, 10$ & $x$ & 直 & $x$ 店 & 0.07 & 0.98 & 0.1 & 0.95 & 0.006517 & 1.520512 & 0.0099092 \\
\hline $18-311$ & $x$ & $x$ & 勾论 & 0.07 & 0.02 & 0.9 & 0.95 & 0.001197 & 1.629824 & 0.0019509 \\
\hline $1, y-312$ & [1] & L & $x$ & 0.93 & 0.98 & 0.9 & 0.05 & 0.041013 & 1.897728 & 0.0778315 \\
\hline せ $\Lambda$ « & $x$ & th & 勻 & 0.07 & 0.98 & 0.9 & 0.95 & 0.058653 & 1.842176 & 0.1080491 \\
\hline$\Lambda \circ y-j 14$ & 计 & $x$ & 匇放 & 0.93 & 0.02 & 0.9 & 0.95 & 0.015903 & 1.94432 & 0.0309205 \\
\hline ハis $y-\dot{\nu} 15$ & (1) & th & $x$ 站 & 0.93 & 0.98 & 0.1 & 0.95 & 0.086583 & 1.91744 & 0.1660177 \\
\hline 11タ-う16 & 田 & & 勻出 & 0.93 & \begin{tabular}{|l|}
0.98 \\
\end{tabular} & 0.9 & 0.95 & 0.779247 & 2.016896 & 1.5716602 \\
\hline
\end{tabular}

\begin{tabular}{|c|c|c|c|c|c|}
\hline & $\begin{array}{l}1 \text { 階で出火 } \\
\text { したとき }\end{array}$ & $\begin{array}{l}\text { 2階で出火 } \\
\text { したとき }\end{array}$ & $\begin{array}{l}\text { 3階で出火 } \\
\text { したとき }\end{array}$ & $\begin{array}{l}\text { 4階で出火 } \\
\text { したとき }\end{array}$ & $\begin{array}{l}5 \text { 階で出火 } \\
\text { したととき }\end{array}$ \\
\hline 5階の避難限界時間(S) & 153 & 156 & $\begin{array}{r}164 \\
\end{array}$ & 182 & 148 \\
\hline 避難開始時間 (S) & 144 & 146 & 148 & 154 & 74 \\
\hline 4階の避難限界時間(S) & 153 & 156 & 164 & 148 & \\
\hline 避難開始時間(S) & 144 & 146 & 148 & 74 & 28 \\
\hline 3階の避難限界時間(S) & 153 & 156 & 148 & & \\
\hline 避難開始時間(S) & 144 & 146 & 74 & Wh & 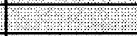 \\
\hline 2階の避難限界時間 (S) & 153 & 148 & & 1. & \\
\hline 避難開始時間(S) & 144 & 74 & Ping & प: & WI: \\
\hline 1階の避難限界時間 $(\mathrm{S})$ & 148 & I= & & & \\
\hline 避難開始時間 (S) & 74 & & & T. & m? \\
\hline
\end{tabular}

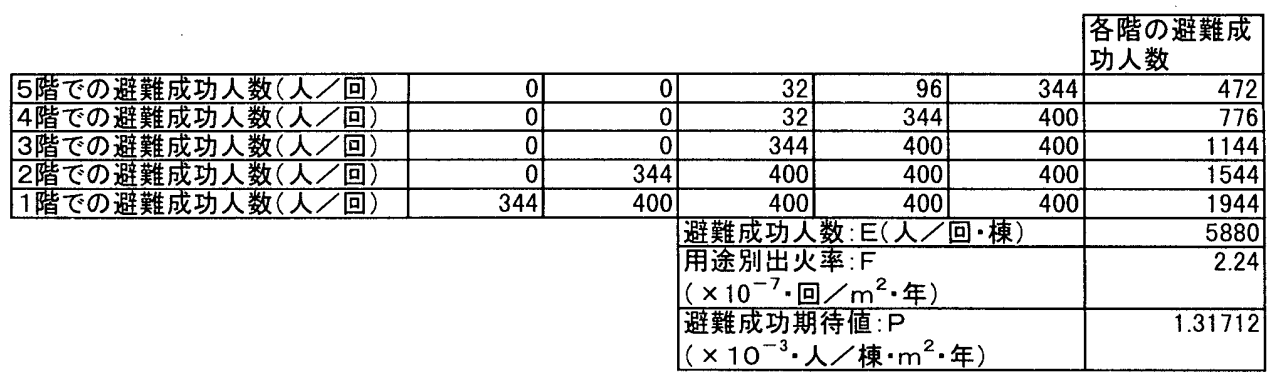

表 9 避難安全性計算結果

\begin{tabular}{|l|r|}
\hline & $\begin{array}{l}\text { 避難安全性: Pr } \\
\left(10^{-3} \cdot \hat{\gamma} / \text { 棟· }\right. \\
\left.\mathrm{m}^{2} \cdot \text { 年 }\right)\end{array}$ \\
\hline CASE1 & 1.317 \\
\hline CASE2 & 1.668 \\
\hline CASE3 & 1.477 \\
\hline CASE4 & 1.516 \\
\hline CASE5 & 1.365 \\
\hline CASE6 & 1.736 \\
\hline CASE7 & 1.889 \\
\hline CASE8 & 1.737 \\
\hline CASE9 & 1.693 \\
\hline CASE10 & 1.515 \\
\hline CASE11 & 1.599 \\
\hline CASE12 & 1.870 \\
\hline CASE13 & 1.800 \\
\hline CASE14 & 1.903 \\
\hline CASE15 & 1.879 \\
\hline CASE16 & 1.985 \\
\hline
\end{tabular}

图 5 避難成功期待值予測結果の 1 例（CASE1） 
CASE16は 4 つの防火対策がすべて設置されているので，すべて の防火対策の作動するかしないかの組み合わせ（パターン 1 16) について，そのパターンの発生確率を求める。それぞれのパターン について表 8 にある避難成功期待值と発生確率とをかけあわせ，さ らにそれらの総和が CASE16の避難安全性：Pr となる。

CASE1〜CASE16のそれぞれについて, 避難安全性を求めた結果 を表 9 に示す。

\section{3 防火コストの算出}

1) イニシャルコスト

4.1で示した単価をもとに, モデル建築物の各防火対策に要するイ ニシャルコストを算出すると，表10のようになる。モデル建築物は 延べ面積が $10 ; 000 \mathrm{~m}^{2}$ であるため，自火報，排煙設備については $15,000 \mathrm{~m}^{2} と 6,000 \mathrm{~m}^{2}$ の中間の值を，スプリンクラーについては $30,000 \mathrm{~m}^{2}$ の值を採用した。また，年間のイニシャルコストを算出す るため設備の耐用年数を 15 年と見積もり，1/15を乗じている。

2).ランニングコスト

4.2 1)で示した方法で概算した，A 社における事務所ビルの保

表10、イニシャルコスト

\begin{tabular}{|c|c|c|}
\hline 防火対策 & 単価 & $\begin{array}{l}\text { 1ニシャルコス } \\
\text { (千丹 }\end{array}$ \\
\hline 自火報 & $4,295\left(\right.$ 円 $/$ 延 $m^{2}$ ) & 2,863 \\
\hline スプリソクラー & $4,700\left(\right.$ 月 $\left./ \mathrm{Z}^{-} \mathrm{m}^{2}\right)$ & 3,133 \\
\hline 防火戸 & 300,000 (円 / 枚) & 400 \\
\hline 排煙設備 & $500\left(\right.$ 円 $/$ 延 $\mathrm{m}^{2}$ ) & 333 \\
\hline
\end{tabular}

表11 保全業務費

\begin{tabular}{|c|c|c|c|c|c|c|}
\hline 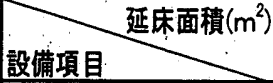 & 30,000 & 15,000 & 10,000 & 6,000 & 3,000 & 単位 \\
\hline 自火報 & 1800 & 1200 & 800 & 720 & 480 & (千月/年) \\
\hline スプリンクラー & 1350 & 900 & 600 & - & - & (千円 /年) \\
\hline 防火戸 & 450 & 300 & 200 & 180 & 120 & (千丹/年) \\
\hline 排煙設備 & 900 & 600 & 400 & - & - & (千円/年) \\
\hline
\end{tabular}

表12 防火コスト

\begin{tabular}{|c|c|c|c|}
\hline & 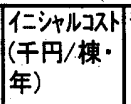 & 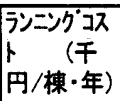 & \begin{tabular}{|l|} 
防火コスㅏ \\
(千円/ \\
棟·年)
\end{tabular} \\
\hline CASE1 & 0 & 886 & 886 \\
\hline CASE2 & 2863 & 1641 & 4,504 \\
\hline CASE 3 & 3133 & 1397 & 4,530 \\
\hline CASE 4 & 400 & 1086 & 1,486 \\
\hline CASE 5 & 333 & 1286 & 1,619 \\
\hline CASE 6 & 5997 & 2197 & 8,194 \\
\hline CASE 7 & 3263 & 1841 & 5,104 \\
\hline CASE 8 & 3197 & 2041 & 5,238 \\
\hline CASE 9 & 3533 & 1597 & 5,130 \\
\hline CASE10 & 3467 & 1797 & 5,264 \\
\hline CASE11 & 733 & 1486 & 2,219 \\
\hline CASE 12 & 6397 & 2397 & 8,794 \\
\hline CASE 13 & 3867 & 1997 & 5,864 \\
\hline CASE 14 & 3597 & 2241 & 5,838 \\
\hline CASE15 & 6330 & 2597 & 8,927 \\
\hline CASE16 & 6730 & 2797 & 9,527 \\
\hline
\end{tabular}

表13 ケーススタディ結果

\begin{tabular}{|c|c|c|}
\hline & $\begin{array}{l}\text { 避難安全性: } \\
\operatorname{Pr}\left(10^{-3} \hat{\imath} \cdot /\right. \\
\text { 棟·的年 } \text { 年 })\end{array}$ & 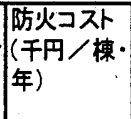 \\
\hline CASE1 & 1.317 & 0 \\
\hline CASE 2 & 1.668 & 2,863 \\
\hline CASE3 & 1.477 & 3,133 \\
\hline CASE 4 & 1.516 & 400 \\
\hline CASE5 & 1.365 & 333 \\
\hline CASE 6 & 1.736 & 5,997 \\
\hline CASE 7 & 1.889 & 3,263 \\
\hline CASE8 & 1.737 & 3,197 \\
\hline CASE 9 & 1.693 & 3,533 \\
\hline CASE10 & 1.515 & 3,467 \\
\hline CASE11 & 1.599 & 733 \\
\hline CASE12 & 1.870 & 6,397 \\
\hline CASE 13 & 1.800 & 3,867 \\
\hline CASE14 & 1.903 & 3,597 \\
\hline CASE15 & 1.879 & 6,330 \\
\hline CASE16 & 1.985 & 6,730 \\
\hline
\end{tabular}

全業務費（表11）から, 建物規模 $10,000 \mathrm{~m}^{2}$ の值を採用する。保全業 務の内容は外観点検, 機能点検, 総合点㭘からなり, 外観点検, 機 能点検は 6 ケ月に 1 回, 総合点検は年に 1 回行うものとする。

次に4.2 2）で示した方法で火災保険料を算出する。

当モデルの場合, 軀体工事, 仕上げ工事, 設備工事を合わせた工 事原価は, $260.6\left(千 円 / \mathrm{m}^{2}\right)^{16)}$, 保険料率は, 東京都 2 等地で, 構造

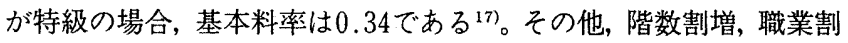
增は当モデルには要しない。

$$
\begin{aligned}
\text { 火災保険料 } & =260.6\left(\text { 千円 } / \mathrm{m}^{2}\right) \times 10,000\left(\mathrm{~m}^{2}\right) \times 0.34 / 1000 \\
& =886(\text { 千円 } / \text { 年 })
\end{aligned}
$$

消火設備割引は, 昼夜を通じ, 管理人が常駐するときのみ適用さ れる。消火設備割引の対象となる防火対策とその割引率は保険会社 の一般的な数值を用いて自火報で $5 \%$ ，スプリンクラーで $10 \%$ と設 定した。

また，消火設備が 2 種類以上設置されているときの割引率も定め られている。自火報と屋内消火栓，またスプリンクラーと屋内消火 栓等，防火対策の組み合わせによっては割引率を加算する場合があ るが，自火報とスプリンクラーの組み合わせに割引率は加算されて いない。

以上をまとめると, CASE1〜CASE16における防火コス卜は表 12 のようになる。

\section{4 ケーススタディ結果}

5.2，5.3の結果から，このモデル建築物における避難安全性と防 火コストの算定結果を表 13 , 図 6 , 図 7 に示す。

今回対象とした 4 つの防火対策のうち単体では，避難安全性の高 い順に, 自火報, 防火戸，スプリンクラー, 排煙設備であり，一方 防火コストの高い順に自火報, スプリンクラー, 排煙設備, 防火户 という結果となった(図 6：CASE2〜CASE5)。自火報は煙の流動 には関係せず避難行動のみに影響するが，自火報を設置することに より他の防火対策を設置するよりも高い避難安全性が得られるとい うことは, 火災の規模や形態に関わらず早期の避難が安全性に大き く影響することが分かる。また, 自火報に次いで避難安全性が高かっ た防火戸に関しては, 防火区画の重要性を表しているものと考えら

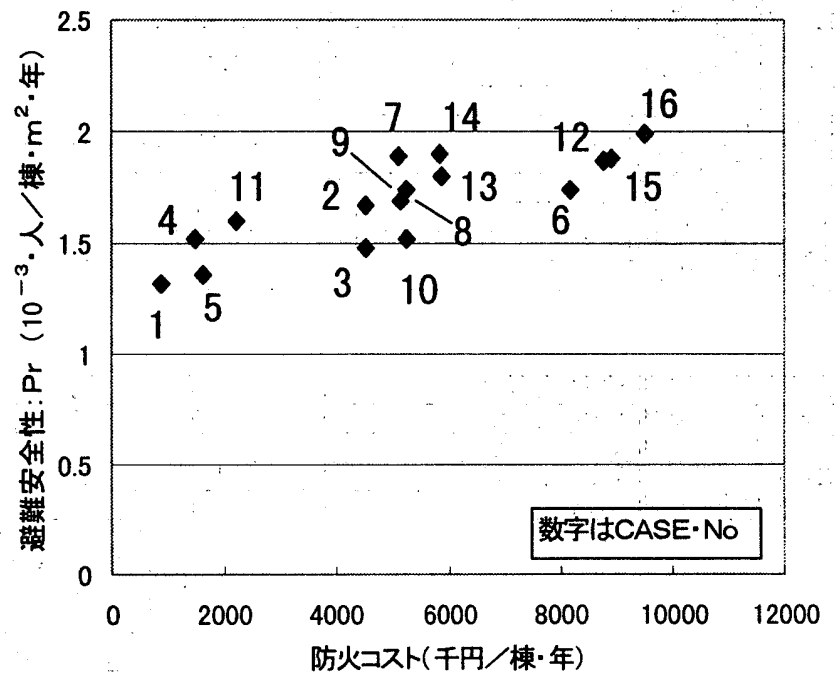

图6 ケーススタディ結果グラフ 


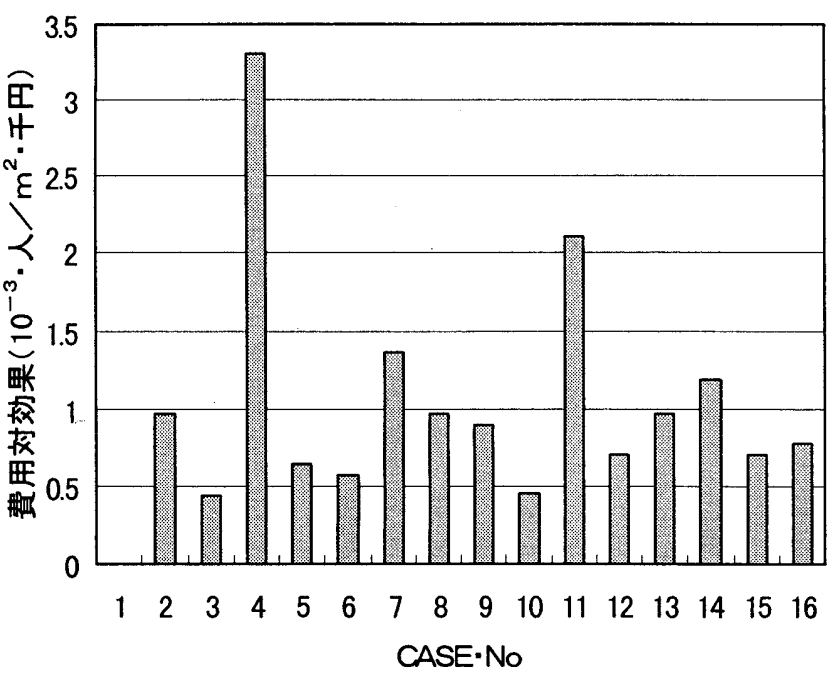

図7 防火対策組み合わせ別・費用対効果

れる。

CASE7〜CASE10の結果を見ると，防火コストはほぼ同額である が避難安全性に差がある。このような結果から，防火対策の組み合 わせによる効果が明らかになる。

また，「避難安全性」と「防火コス卜」のそれぞれについて，防火 対策を設置していないCASE1との差をとり，防火对策を設置する ことによりどれだけの避難安全性が得られるかをコストあたりで評 価したグラフを図 7 に示す。防火戸が圧倒的に効率の良い防火对策 という結果となった(CASE4)。ただし，これらの結果はいずれも本 報で行った，事務所ビルを対象としたケーススタディによる結果で ある。

\section{6.まとめ}

本報では，防火対策の設置の有無と信頼度を考慮した避難安全性 と防火コストの算出方法を提案し，事務所ビルに関してのケースス タデイを行った。その結果，以下の知見が得られた。

1）組み合わせる防火対策の数が多いほど，避難安全性は增大する 傾向がある。

2 ）自火報, スプリンクラー，防火戸，排煙設備のうち，避難安全 性については，単体では自火報が最も高く，次いで防火戸，スプ リンクラー，排煙設備という結果となった。

3) 防火コストとの関係で最も効率の良い防火対策は防火戸，次い で自火報，排煙設備，スプリンクラーである。

4）防火対策の組み合わせにより，防火コストはほぼ同じでも避難 安全性には差がつく場合がある。

本報では自火報や防火戸は相対的に避難安全性が高いという結果 となったが，これらはいずれも奏功率については，一般的にあまり 良くないとされている。防火戸が，建物の使われ方により閉まらな

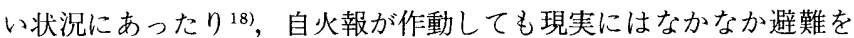

開始しない199などがその例である。一方，スプリンクラーは奏功率が かなり高いことが報告されている7)。今回はパラメーターとして「信 頼度」を用いたが，「奏功率」を用いた評価システムを構築すること により，今後はより現実的な評価ができるものと考える。

また，对象とする防火対策の選定，各防火対策の信頼度や組み合 わせ，避難開始時間，防火コストの算出等については暫定的に設定 し，比較を行ったが，さらにそれぞれの設定值についての詳細な裹 付けが必要である。

本報では一つのモデル建築物を想定して，コストを考慮した防火 対策の効果を評価する方法について提案した。今回は対象とした 4 つの防火对策単体や任意の組み合わせについての費用対効果を示す にとどまったが，今後，確保されるべき安全性のレベルと適正な投 資レベルが設定されれば，そのレベルで防火対策の効果について評 価を行うことが重要である。そして様々な規模や用途，プランの建 物，さらには実物件への適用についても検討し，評価手法を確立す ることにより,性能規定化に向けた防火計画の一案となると考之る。

\section{参考文献}

1）(社建築業協会防災計画技術小委員会, 防災計画に関する設計者の問題意識 アンケート調查(その 1)（その 2), 火災 No. 220, No. 221, 1996.2, 1996.4 BCS 防災計画技術小委員会平成 6 年度活動報告, 1995.7

2）原田和典：予測計算手法を利用した火災安全設計, 1996年度日本建築学会 大会学術講演梗概集 No. 3036, 日本建築学会, 1996.9

3）掛川秀史：火災シナリオに基づく避難安全性評価手法に関する研究, 名古 屋大学博士論文, 1997.7

4）中村裕幸：建築における防火設備コストの分析, 建築設備と配管工事, 1985.2

5）中村裕幸：建設コストと防災投資，建築の技術＼cjkstart施工，1983.1

6）鈴木恵子：建築物の防火投資に関する研究，神戸大学修士論文， 1994.2

7）中嶋久枝：防火コストを考慮した最適防火設計法に関する基礎的研究, 神 戸大学修士論文, 1995.2

8）建設省大臣官房技術調査公監修：建築物の総合防火設計法 第 3 巻, 避難 安全設計法, P.89 P.90, P.100, 日本建築センター, 1989.4

9）田中哮義他 5 名：煙流動及び避難性状予測のための実用計算プログラム 解説書 (第 2 版)，日本建筑センター，1992.5

10）建設省住宅局建築指導課，日本建築主事会議監修：新·建築防災計画指針, 日本建築センター-, P.143，1995.7

11）堀内三郎他 2 名：新版，建築防火，朝倉書店，P.104， 1994.8

12）デザイナーのための見積チェックリスト 1994年度版, 建築文化別冊, 彰 国社編，P.132 P.134，1994.3

13）时経济調查会：月刊積算資料，財経済調查会，P.384，1994.11

14）建設大臣官房官庁営縉部監修：建築保全業務積算基準, 平成 6 年度版, 財) 経済調查会，P.78～P.123，1994.4

15）朴 哲也：建築物の出火率と防災設備の故障率に関する統計的研究, 名古 屋大学博士論文, P.71，1991.1

16）建築工事原価分析情報，建設工業経営研究会，P.56 P.63，1992.8

17）火災保険一般物件料率表，損害保険料率算定会， P.64， P.66， P.75，1990.4

18）特殊建築物等調査資格者講習テキス卜, 僛日本建築防災協会, P.448, 1995.8

19）中野美奈他 5 名：広島基町高層住宅火災時における避難行動調查, 1997年 度日本建築学会大会学術講演梗概集 No. 3048, 日本建築学会, 1997.7

（1998年 4 月10日原稿受理，1998年 9 月18日採用決定） 